Mediterranean Journal of Humanities

mjh.akdeniz.edu.tr

III/2, 2013, 193-208

\title{
The Effect of Semantic and Thematic Lists on EFL Learners' Vocabulary Retention: Self-regulatory Behaviors Compared
}

\author{
EFL Öğrencilerin Kelime Kalıcılı̆̆ı Üzerine Semantik ve Tematik Listelerin \\ Etkisi: Öz-Düzenleyici Davranışların Karşılaş̧ırılması
}

\section{Masoumeh MEHREGAN*}

\begin{abstract}
The present study aimed to compare the long-term and short-term effects of semantic and thematic clustering on Iranian learners' vocabulary acquisition. The study was also an attempt to evaluate the effects of these clustering types on learners' self-regulatory behaviors. Two groups of language learners were asked to study two word lists, one semantic $(\mathrm{N}=30)$ and the other thematic $(\mathrm{N}=30)$ clusters. After the participants finished studying the word lists that contained the definition of words and Persian equivalents, the word lists were collected and then they were given a list of the same words without the Persian equivalents. The participants were asked to provide the equivalents right after collecting the papers to consider short-term effects and also two weeks later to consider long-term effects. Results of statistical analyses showed that participants recalled the words from the thematic list as well as from the semantic list. Moreover, their self-regulatory attitudes towards the clustering types remained the same.
\end{abstract}

Keywords: Vocabulary acquisition, semantic clustering, thematic clustering, self-regulation

Özet: Mevcut çalışma, semantik ve tematik kümelemenin İranlı öğrencilerin kelime edinimleri üzerindeki uzun ve kısa dönemli etkilerinin karşılaştırılmasını hedeflemiştir. Çalışma aynı zamanda, bu kümeleme tiplerinin öğrencilerin öz-düzenleyici davranışları üzerindeki etkilerini değerlendirmek için bir deneme idi. Dil öğrencilerinden oluşan iki gruptan iki kelime listesini çalışmaları istendi, biri semantik $(\mathrm{N}=30)$ ve diğeri tematik ( $\mathrm{N}=30)$ kümeler. Katılımcılar, kelimelerin anlamlarını ve Persçe mudaillerini içeren kelime listelerine çalışmayı bitirdikten sonra, kelime listeleri toplandı ve daha sonra katılımcılara Persçe muadilleri olmayan aynı kelimelerin bir listesi verildi. Kağıtları, kısa dönem etkileri gözlemlemek ve aynı zamanda iki hafta sonra da uzun dönemli etkileri gözlemlemek için topladıktan sonra, katılımcılardan muadilleri doğru bir biçimde sunmaları istendi. İstatistiksel analizlerin sonuçları gösterdi ki, katılımcılar semantik listeden olduğu kadar tematik listeden kelimeleri de hatırladılar. Dahası, kümeleme tiplerine karşı kendi öz-düzenleyici davranışları aynı kaldı.

Anahtar sözcükler: Kelime edinimi, semantik kümeleme, tematik kümeleme, öz-düzenleme

\section{Introduction}

Second language vocabulary acquisition is seen by many teachers and learners as the single most significant element of language learning. Not only do the majority of learners consider vocabulary as their precedence, but it is usually identified as a priority by teachers too. The fact that vocabulary constitutes a central role in textbook selection and preparation for the classroom by teachers is also confirmed by different scholars. Schmitt (1999), for example, refers to the

\footnotetext{
*MA. in TEFL, Isfahan University, İran, mehregan56@yahoo.com
} 
major role of vocabulary knowledge in L2 proficiency. Knight (1994) regards it as the one most important component in foreign language learning. Healey (2000) believes in the power of explicit and intentional vocabulary study since a large number of words can precipitate the learning process and turn learning into an enjoyable task.

In experiential and practical contexts, learners with a vast knowledge of words can be more communicatively effective than those with a limited body of knowledge (Meara, \& Fitzpatrick, 2000). In addition, vocabulary knowledge can be a strong predictor of all language skills including reading comprehension, writing, listening and speaking abilities. It is therefore apparent that acceptable level of vocabulary is a prerequisite for successful language acquisition. Adequate vocabulary skills are indispensable for effective communication in all aspects of second language learning.

In spite of the significance of vocabulary in language learning, certain difficulties are associated with it. For instance, vocabulary acquisition is considered to be a slow and incremental process (Miller, \& Gilda, 1987). Subsequent integration of lexical items into learners' initial repertoire needs a repeated input process during numerous encounters with the word. It is evident that vocabulary learning is a challenge to many foreign language learners in terms of time limitations, lack of exposure to authentic learning contexts, and lack of effective vocabulary strategies. However, recent years have marked attempts that have been made to present strategies and methods for vocabulary learning and there are many issues related to lexical learning which are yet to be investigated for their effectiveness. One such influential discussion has been the usability and appropriateness of vocabulary clusters. The literature review on vocabulary lists suggests that word clusters can help accelerate the language learning process.

\section{Vocabulary Clustering}

In order to help learners read texts easily with a high degree of comprehension, researchers investigated more beneficial ways of teaching L2 vocabulary. One significant argument over the years has been the distinction between incidental and intentional vocabulary learning (Hulstijn, 1992, 2001; Gass, 1999; Barcroft, 2009; Bruton, Lopez, \& Mesa, 2011). The difference between the two learning conditions has been ascribed to the pedagogical context of the learning, learner attention and involvement, and the activity or task (Read, 2004). Both incidental and intentional learning conditions have been reasoned to lead to the incremental learning of second language vocabulary (Parry, 1997; Paribakht, \& Wesche, 1997; Hulstijn, 2001). However, the present study focuses on the intentional learning of vocabulary items and the most effective learning method during intentional learning.

A considerable amount of research was conducted, specifically in the 1960s, on list learning as a type of intentional word learning (e.g., Murdock, 1962; Segal, \& Mandler, 1967; Tulving, 1968). Regardless of the growing interest in second language vocabulary learning, the effective kind of vocabulary learning has been an area which has escaped attention.

The types of the words that learners retain along with the target items (word clusters) are the forces that influence the efficiency of vocabulary acquisition. There have been a few studies looking at this impact, but there has been no agreement about the results (Erten, \& Tekin, 2008). Gairns and Redman (1986) evaluated the arguments regarding the usefulness of semantic clustering in facilitating the learning of new words. These assortments, such as ear, eye, nose, mouth are named by some scholars as lexical sets (e.g., Gairns, \& Redman, 1986) while others (e.g., Marzano, \& Marzano, 1988) use the title semantic clusters. The notion is that learning the 
concept 'ear' is facilitated by knowing how ears are both similar to and different from eyes and noses. The use of semantic sets in learning vocabulary gets its strength from the semantic fields theory which provides evidence for the effectiveness of providing semantically related words. The assumption is that semantic lists can lead to a) similar approaches of generating complex lexical networks (Amer, 1986), b) beneficial learning of the words, where learning a new word encourages learning of its neighbors (Seal, 1991), and c) a way of showing the dissemination of meaning of related vocabulary items (Dunbar, 1992).

In spite of the positive points cited for the use of semantic clusters, there are some researchers who disprove the efficiency of semantic groups (e.g., Tinkham, 1997; Finkbeiner, \& Nicol, 2003; Erten, \& Tekin, 2008; Hoshino, 2010; Tagashira, Kida, \& Hoshino, 2010). Different theories are referred to by the opponents of semantic lists. One such theory is the interference theory, according to which similar words can interfere with each other, thereby leading to learning difficulties. According to interference theory, as the similarity between the information intended to be acquired and the information learnt before or after that information grows, the difficulty of learning that information also expands (Tinkham, 1997). There are many studies which have found that near-simultaneous exposure to semantically and syntactically related words can hinder rather than ease the process of word learning (Crowder, 1976). Another piece of evidence against the use of semantic lists is the distinctive hypothesis (Eyseck, 1979). According to this hypothesis, learners can benefit more from distinguished and disparate items. The studies of distinctiveness and memory provided contrary effects of the semantic linkage in recalling the lexical information (Hunt, \& Worthen, 2006).

Although semantic lists are consistent with different EFL methodologies and they emphasize the similarities and differences among words, there is little or no evidence supporting the positive influence of semantic clusters upon the learning of L2 vocabulary items.

Because of the divisions that exist with the notion of semantic lists, Tinkham (1997) presented thematic clustering as a more appropriate alternative. Thematic words are classified according to the frames or schemes whose meaning they share. A group of words derived from such a frame can include apple, green, eat, tree and farm, which are words of different structures that are closely linked with a joint thematic concept. Since these groups are based on associative strength, they are cognitively rather than linguistically obtained and as a result would be compatible with learning-centered language teaching programs which mainly pertain to the learning processes than the linguistic analysis. In sum, semantic clustering relies on semantic and syntactic similarities among listed words and thematic clustering are dependent upon the psychological attachments between grouped words and a shared thematic notion.

The main rationalization for the use of thematic clustering is schema theory. Schema can facilitate learning since schema-related information is much easier to learn than schemaunrelated information. In thematic clustering, then, learners actively classify the past responses or skills with the new information (Celce-Murciai, \& Olshtain, 2000). Several scholars justified presenting words in thematic clustering which can facilitate the process of vocabulary acquisition and therefore avoid the undesirable effects (e.g., Fillmore, \& Atkins, 1992; Tinkham, 1993, 1997; Al-Jabri, 2005; Motallebzadehi, \& Heirany, 2011; Mirjalali et alii., 2012).

Although these two methods of organizing vocabulary items are distinguishable and are both used in L2 vocabulary teaching programs, research into the impacts of clustering on L2 vocabulary learning is very restricted. The researchers did not directly evaluate the effects of theme-based groupings on L2 vocabulary acquisition. Considering this gap in the literature, the present study is motivated to investigate the effects of semantic and thematic clustering on the 
learning of new vocabulary items. In addition, this study probes into the effectiveness of these clustering types in terms of their contribution to learners' self-regulatory behaviors in vocabulary learning. More specifically, the following research questions are addressed in the study:

1) Is there any significant difference between learners' immediate vocabulary learning with regard to semantic and thematic clustering of L2 words?

2) Is there any significant difference between learners' delayed vocabulary learning with regard to semantic and thematic clustering of L2 words?

3) Is there any significant difference between learners' semantic and thematic vocabulary learning with regard to their self-regulatory behaviors?

\section{Methodology}

Participants studied two lists of English words representing semantic clustering and thematic clustering. In the first phase of the study, lists of English words representing semantic clustering and thematic clustering were given to the students before starting the class and they were asked to complete the task immediately; for the purpose of immediate recall test. In the second phase of the study, about two weeks later students were asked to write the words they remembered from semantic or thematic clusters; for the purpose of delayed recall test.

The details of participants, materials and procedures are given below.

\section{Subjects}

The current study was an attempt to examine L2 vocabulary learning through semantic and thematic sets among Iranian intermediate level of proficiency learners. In the first part, data were collected from 60 participants, studying English in one of language centers in Tehran, Iran. They were male and female learners randomly selected and randomly assigned to either a semantic or thematic group. The participations were told that their participation in the study was voluntary and their identity would be kept confidential.

\section{Materials}

The purpose of this study was to compare the learnability of semantic and thematic sets of English words. The words were accompanied by definitions and examples and also Persian equivalents to make sure that the participants could fully understand and perceive the meaning of the words, especially at the elementary level. Two lists were used; each consisted of ten English words. The first list related to semantic clustering and included ten English (L2) words of different construction instruments (See Appendix A). The second list related to thematic clustering and included ten English (L2) words related to the theme of "The Picnic" and were thematically related (See Appendix B). For instance, words used in the theme of having a typical picnic. The semantic set included words related in meaning or words belonging to the same semantic domain. For instance, words connected to the notion of ways of looking were presented together such as: stare, gaze, glare, glance, glimpse, blink, wink, peer, and peep. The thematic set included vocabulary items that belonged to a certain schema or theme or thematically associated words such as: frog, green, hop, pond, slippery, croak.

It is important to note that the selected words were infrequent or unknown ones to ensure that the words were new to the students, but their meanings or Persian equivalents were completely known and familiar to the students; in other words, they had the concept or background knowledge of the given object (Tinkham, 1993, 1997; Waring, 1997). Meanwhile, students were supplied with the meaning and definition accompanied by simple examples of the lexical items to make sure that the participants could fully understand and perceive the meaning 
of the words.

The last instrument that was used for eliciting data on learners' sense of self-regulation was the self-regulating capacity in vocabulary learning scale (SRCvoc) developed by Tseng et al. (2006). The instrument was based on a theoretical construct from the area of educational psychology developed by Dörnyei (2005). The SRCvoc is a 6-point Likert scale (6 = strongly agree; 1 = strongly disagree) questionnaire. Each of the five facets in the scale included four items. The instrument was used in its original form without any modifications.

\section{Procedure}

Participants were divided into two groups, corresponding to the two learning conditions. Half of the participants took the semantic list and the remaining took the thematic list to ensure that both situations had the same condition. One list consisted of ten semantically related English words accompanied by their Persian equivalents and English definitions and simple examples. Subjects were required to study them for a total of five minutes, that is, 30 seconds per item. After five minutes, the participants were instructed to stop referring to the lists, and the immediate recall phase took place. Each subject was required to turn to the following page, which contained the ten English words, and to provide their Persian equivalents. In order to eliminate any chance of memorizing the list as a whole rather than learning words, the participants were informed that the words on the test were arranged in a different sequence.

Translation in the L2-L1 rather than L1-L2 direction is efficient (Nation, 2001). In this regard Prince (1996) states that using translation in the L2-L1 direction improves recall performance. He found that weak learners even significantly outperformed advanced learners when translation was in L2-L1 direction. Studies of bilingual translation (Kroll, \& Curley, 1986; Kroll, \& Stewart, 1989) found that learners were faster when translating into their first language than into their second language. The reason behind this is provided by Kroll and Stewart (1994): For most bilinguals, even those who are relatively fluent, more words are known in the native than in the second language. Lexical associations from L2 to L1 are assumed to be stronger than those from L1 to L2 because L2 to L1 is the direction in which second language learners first acquire the translations of new L2 words. Therefore, it should be easier for a Persian speaker to retrieve a Persian word from memory when given the English word than to retrieve an English word when given the Persian word.

In order to investigate the effect of delayed vocabulary retention, after two weeks a post-test was given to both level learners. When the class time was over, students were given the lists. The lists were the same as those in immediate recall test and students were required to write the Persian equivalents. There was no time limit for the completion of tests.

\section{Results}

In order to investigate the differences between immediate and delayed retention of vocabularies in semantic and thematic clustering types, one-way ANOVAs were conducted. The analyses were arranged according to three vocabulary learning conditions of recalled, interfered, and forgotten. Also, in order to have a holistic view of the general differences between the thematic and semantic clustering of each proficiency level, an independent samples T-test was conducted. Moreover, an independent samples T-test was run to evaluate learners' self-regulatory differences in two word clustering conditions. The results are shown below.

The descriptive statistics for the differences in the different conditions (recalled, interfered, and forgotten) of semantic clustering on learners' immediate vocabulary retention are reported in table 4.1. 
Table 4.1. Vocabulary Retention in Immediate Semantic Test

\begin{tabular}{|l|l|c|c|c|c|c|c|c|}
\hline & \multirow{2}{*}{$\mathrm{N}$} & \multirow{2}{*}{ Mean } & \multirow{2}{*}{$\begin{array}{c}\text { Std. } \\
\text { Deviation }\end{array}$} & \multirow{2}{*}{ Std. Error } & \multicolumn{2}{|c|}{$\begin{array}{c}\text { 95\% Confidence } \\
\text { Interval for Mean }\end{array}$} & \multirow{2}{*}{ Minimum } & Maximum \\
\cline { 5 - 8 } & & & & $\begin{array}{c}\text { Lower } \\
\text { Bound }\end{array}$ & $\begin{array}{c}\text { Upper } \\
\text { Bound }\end{array}$ & & \\
\hline Recalled & 30 & 8.3333 & .84418 & .15413 & 8.0181 & 8.6486 & 7.00 & 10.00 \\
\hline Interfered & 30 & .5000 & .57235 & .10450 & .2863 & .7137 & .00 & 2.00 \\
\hline Forgotten & 30 & 1.1667 & .64772 & .11826 & .9248 & 1.4085 & .00 & 2.00 \\
\hline Total & 90 & 3.3333 & 3.63194 & .38284 & 2.5726 & 4.0940 & .00 & 10.00 \\
\hline
\end{tabular}

As the above table shows, most of the participants $(\mathrm{M}=8.33)$ in this study recalled the immediately presented vocabulary items and only some of them have forgotten the items. However, to get more reliable results, a one-way ANOVA test was run. The results are shown in tables 4.2 and 4.3 below.

Table 4.2. ANOVA Results for Vocabulary Retention in Immediate Semantic Test

\begin{tabular}{|l|c|c|c|c|c|}
\hline & $\begin{array}{c}\text { Sum of } \\
\text { Squares }\end{array}$ & df & $\begin{array}{c}\text { Mean } \\
\text { Square }\end{array}$ & F & Sig. \\
\hline Between Groups & 1131.667 & 2 & 565.833 & 1.1633 & .000 \\
\hline Within Groups & 42.333 & 87 & .487 & & \\
\hline Total & 1174.000 & 89 & & & \\
\hline
\end{tabular}

The results of one-way ANOVA show statistically significant differences $(F(89)=1.1633, \mathrm{p}=$ 0.000 ) between the different conditions in immediate semantic clustering type. However, to place the exact points of differences a Tukey post-hoc test was conducted. Results of the Tukey test are shown below.

Table 4.3. Tukey Test Results for Vocabulary Retention in Immediate Semantic Test

\begin{tabular}{|c|c|c|c|c|c|c|}
\hline \multirow{2}{*}{ (I)condition.semantic.1 } & \multirow{2}{*}{ (J)condition.semantic.1 } & \multirow{2}{*}{$\begin{array}{c}\text { Mean } \\
\text { Difference } \\
(\mathrm{I}-\mathrm{J})\end{array}$} & \multirow{2}{*}{$\begin{array}{l}\text { Std. } \\
\text { Error }\end{array}$} & \multirow{2}{*}{ Sig. } & \multicolumn{2}{|c|}{$\begin{array}{l}\text { 95\% Confidence } \\
\text { Interval }\end{array}$} \\
\hline & & & & & $\begin{array}{l}\text { Lower } \\
\text { Bound }\end{array}$ & $\begin{array}{l}\text { Upper } \\
\text { Bound }\end{array}$ \\
\hline \multirow{2}{*}{ Recalled } & interfered & $7.83333^{*}$ & 18011 & .000 & 7.4039 & 8.2628 \\
\hline & forgotten & $7.16667^{*}$ & .18011 & .000 & 6.7372 & 7.5961 \\
\hline \multirow{2}{*}{ Interfered } & recalled & $-7.83333^{*}$ & .18011 & .000 & -8.2628 & -7.4039 \\
\hline & forgotten & $-.66667^{*}$ & .18011 & .001 & -1.0961 & -.2372 \\
\hline \multirow{2}{*}{ Forgotten } & recalled & $-7.16667^{*}$ & 18011 & .000 & -7.5961 & -6.7372 \\
\hline & interfered & $.66667^{*}$ & .18011 & .001 & .2372 & 1.0961 \\
\hline
\end{tabular}

* The mean difference is significant at the 0.05 level.

As the above Tukey test shows, there are significant differences among the three conditions of semantic clustering with regard to their impact on learners' retention.

In order to investigate the differences among the three conditions of semantic clustering 
with regard to the delayed retention of learners, first descriptive statistics and then one-way ANOVA were carried out. The results are shown in tables 4.4, 4.5 and 4.6 below.

Table 4.4. Vocabulary Retention in Delayed Semantic Test

\begin{tabular}{|c|c|c|c|c|c|c|c|c|}
\hline & \multirow{2}{*}{$\mathrm{N}$} & \multirow{2}{*}{ Mean } & \multirow{2}{*}{$\begin{array}{c}\text { Std. } \\
\text { Deviation }\end{array}$} & \multirow{2}{*}{$\begin{array}{l}\text { Std. } \\
\text { Error }\end{array}$} & \multicolumn{2}{|c|}{$\begin{array}{l}\text { 95\% Confidence } \\
\text { Interval for Mean }\end{array}$} & \multirow{2}{*}{ Minimum } & \multirow{2}{*}{$\begin{array}{c}\text { Maximu } \\
\mathrm{m}\end{array}$} \\
\hline & & & & & $\begin{array}{l}\text { Lower } \\
\text { Bound }\end{array}$ & $\begin{array}{l}\text { Upper } \\
\text { Bound }\end{array}$ & & \\
\hline Recalled & 30 & 7.7000 & 1.29055 & 23562 & 7.2181 & 8.1819 & 6.00 & 10.00 \\
\hline Interfered & 30 & .8667 & .43417 & .07927 & .7045 & 1.0288 & .00 & 2.00 \\
\hline Forgotten & 30 & 1.4333 & .56832 & .10376 & 1.2211 & 1.6455 & .00 & 2.00 \\
\hline Total & 90 & 3.3333 & 3.22560 & 34001 & 2.6577 & 4.0089 & .00 & 10.00 \\
\hline
\end{tabular}

The results of descriptive statistics indicate that learners followed the same pattern in the delayed performance as in immediate performance with regard to vocabulary retention in the semantic clustering. Participants in the delayed condition recalled the vocabulary items and only a few of them have forgotten the items according to the above means and standard deviations. In order to get much more accurate results, a one-way ANOVA test was conducted.

Table 4.5. ANOVA Results for Vocabulary Retention in Delayed Semantic Test

\begin{tabular}{|l|c|c|c|c|c|}
\hline & Sum of Squares & df & Mean Square & F & Sig. \\
\hline Between Groups & 862.867 & 2 & 431.433 & 594.531 & .000 \\
\hline Within Groups & 63.133 & 87 & .726 & & \\
\hline Total & 926.000 & 89 & & & \\
\hline
\end{tabular}

The results of one-way ANOVA show statistically significant differences $(\mathrm{F}(89)=594.53, \mathrm{p}=$ 0.000 ) between the different conditions in delayed semantic clustering type. However, to place the exact points of differences a Tukey post-hoc test was conducted. Results of the Tukey test are shown below.

Table 4.6. Tukey Test Results for Vocabulary Retention in Delayed Semantic Test

\begin{tabular}{|c|c|c|c|c|c|c|}
\hline \multirow{2}{*}{$\begin{array}{l}\text { (I) condition. } \\
\text { semantic.1 }\end{array}$} & \multirow{2}{*}{$\begin{array}{l}\text { (J) condition. } \\
\text { semantic.1 }\end{array}$} & \multirow{2}{*}{$\begin{array}{c}\text { Mean } \\
\text { Difference } \\
(\mathrm{I}-\mathrm{J})\end{array}$} & \multirow{2}{*}{ Std. Error } & \multirow{2}{*}{ Sig. } & \multicolumn{2}{|c|}{$\begin{array}{l}\text { 95\% Confidence } \\
\text { Interval }\end{array}$} \\
\hline & & & & & $\begin{array}{l}\text { Lower } \\
\text { Bound }\end{array}$ & $\begin{array}{l}\text { Upper } \\
\text { Bound }\end{array}$ \\
\hline \multirow{2}{*}{ Recalled } & Interfered & $6.83333^{*}$ & .21995 & .000 & 6.3089 & 7.3578 \\
\hline & Forgotten & $6.26667^{*}$ & .21995 & .000 & 5.7422 & 6.7911 \\
\hline \multirow{2}{*}{ Interfered } & Recalled & $-6.83333^{*}$ & .21995 & .000 & -7.3578 & -6.3089 \\
\hline & Forgotten & $-.56667^{*}$ & .21995 & .031 & -1.0911 & -.0422 \\
\hline \multirow{2}{*}{ Forgotten } & Recalled & $-6.26667^{*}$ & .21995 & .000 & -6.7911 & -5.7422 \\
\hline & Interfered & $.56667^{*}$ & 21995 & .031 & .0422 & 1.0911 \\
\hline
\end{tabular}

* The mean difference is significant at the 0.05 level.

As the above Tukey test shows, there are significant differences among the three conditions of semantic clustering with regard to their impact on learners' delayed retention. 
To examine the differences among the three conditions of immediate thematic clustering in learners' performance, the following procedures were conducted.

First, the descriptive statistics are reported in table 4.7.

Table 4.7. Vocabulary Retention in Immediate Thematic Test

\begin{tabular}{|c|c|c|c|c|c|c|c|c|}
\hline & \multirow{2}{*}{$\mathrm{N}$} & \multirow{2}{*}{ Mean } & \multirow{2}{*}{$\begin{array}{c}\text { Std. } \\
\text { Deviation }\end{array}$} & \multirow{2}{*}{$\begin{array}{l}\text { Std. } \\
\text { Error }\end{array}$} & \multicolumn{2}{|c|}{$\begin{array}{l}\text { 95\% Confidence } \\
\text { Interval for Mean }\end{array}$} & \multirow{2}{*}{ Minimum } & \multirow{2}{*}{ Maximum } \\
\hline & & & & & $\begin{array}{l}\text { Lower } \\
\text { Bound }\end{array}$ & $\begin{array}{l}\text { Upper } \\
\text { Bound }\end{array}$ & & \\
\hline Recalled & 30 & 9.0000 & 1.17444 & .21442 & 8.5615 & 9.4385 & 7.00 & $\begin{array}{l}10.00 \\
\end{array}$ \\
\hline Interfered & 30 & .3333 & .47946 & .08754 & .1543 & .5124 & .00 & 1.00 \\
\hline Forgotten & 30 & .6667 & .60648 & .11073 & .4402 & .8931 & .00 & 2.00 \\
\hline Total & 90 & 3.3333 & 4.11082 & .43332 & 2.4723 & 4.1943 & .00 & 10.00 \\
\hline
\end{tabular}

The results of thematic immediate test are in line with the results of semantic immediate clustering type with regard to the performance of learners. Most of the participants have recalled the learnt vocabulary items in the immediate post-test. Results of one-way ANOVA are shown in table 4.8 .

Table 4.8. ANOVA Results for Vocabulary Retention in Immediate Thematic Test

\begin{tabular}{|l|c|c|c|c|c|}
\hline & Sum of Squares & $\mathrm{df}$ & Mean Square & $\mathrm{F}$ & Sig. \\
\hline Between Groups & 1446.667 & 2 & 723.333 & 1.0983 & .000 \\
\hline Within Groups & 57.333 & 87 & .659 & & \\
\hline Total & 1504.000 & 89 & & & \\
\hline
\end{tabular}

ANOVA results show statistically significant $(F(89)=1.0983, p=0.000)$ differences across the three conditions of immediately presented semantic test. Results of Tukey test are reported below in table 4.9.

Table 4.9. Tukey Test Results for Vocabulary Retention in Immediate Thematic Test

\begin{tabular}{|l|c|c|c|c|c|c|}
\hline $\begin{array}{l}\text { (I) condition. } \\
\text { thematic.1 }\end{array}$ & $\begin{array}{c}\text { (J) condition. } \\
\text { thematic.1 }\end{array}$ & $\begin{array}{c}\text { Mean } \\
\text { Difference (I-J) }\end{array}$ & \multirow{2}{*}{$\begin{array}{c}\text { Std. } \\
\text { Error }\end{array}$} & \multirow{2}{*}{ Sig. } & \multicolumn{2}{|c|}{ 95\% Confidence Interval } \\
\cline { 5 - 7 } Recalled & Interfered & $8.66667^{*}$ & .20960 & .000 & Lower Bound & Upper Bound \\
\cline { 2 - 7 } & Forgotten & $8.33333^{*}$ & .20960 & .000 & 7.8335 & 9.1665 \\
\hline \multirow{2}{*}{ Interfered } & Recalled & $-8.66667^{*}$ & .20960 & .000 & -9.1665 & -8.1663 \\
\cline { 2 - 7 } & Forgotten & -.33333 & .20960 & .255 & -.8331 & .1665 \\
\hline \multirow{2}{*}{ Forgotten } & Recalled & $-8.33333^{*}$ & .20960 & .000 & -8.8331 & -7.8335 \\
\cline { 2 - 7 } & Interfered & .33333 & .20960 & .255 & -.1665 & .8331 \\
\hline
\end{tabular}

* The mean difference is significant at the 0.05 level.

As table 4.9 shows, there are no differences $(\mathrm{p}=0.225)$ between the interfered and forgotten conditions, while there are significant differences $(\mathrm{p}=0.000)$ between the recalled condition and the other two types.

The findings of comparisons among the three conditions of delayed thematic test are presented below. 
Table 4.10. Vocabulary Retention in Delayed Thematic Test

\begin{tabular}{|c|c|c|c|c|c|c|c|c|}
\hline & \multirow{2}{*}{$\mathrm{N}$} & \multirow{2}{*}{ Mean } & \multirow{2}{*}{$\begin{array}{c}\text { Std. } \\
\text { Deviation }\end{array}$} & \multirow{2}{*}{$\begin{array}{l}\text { Std. } \\
\text { Error }\end{array}$} & \multicolumn{2}{|c|}{$\begin{array}{l}\text { 95\% Confidence Interval } \\
\text { for Mean }\end{array}$} & \multirow{2}{*}{ Minimum } & \multirow{2}{*}{ Maximum } \\
\hline & & & & & $\begin{array}{l}\text { Lower } \\
\text { Bound }\end{array}$ & $\begin{array}{l}\text { Upper } \\
\text { Bound }\end{array}$ & & \\
\hline Recalled & 30 & 8.3667 & 1.09807 & .20048 & 7.9566 & 8.7767 & 7.00 & 10.00 \\
\hline Interfered & 30 & .8000 & .40684 & .07428 & .6481 & .9519 & .00 & 1.00 \\
\hline Forgotten & 30 & .8333 & .53067 & .09689 & .6352 & 1.0315 & .00 & 2.00 \\
\hline Total & 90 & 3.3333 & 3.65353 & .38512 & 2.5681 & 4.0986 & .00 & 10.00 \\
\hline
\end{tabular}

Descriptive statistics indicate differences between the three conditions, with the recalled conditions showing the highest degree of performance. Results of one-way ANOVA and Tukey test are reported below.

Table 4.11. ANOVA Results for Vocabulary Retention in Delayed Thematic Test

\begin{tabular}{|l|c|c|c|c|c|}
\hline & $\begin{array}{c}\text { Sum of } \\
\text { Squares }\end{array}$ & df & Mean Square & $\mathrm{F}$ & Sig. \\
\hline Between Groups & 1140.067 & 2 & 570.033 & $1.035 \mathrm{E} 3$ & .000 \\
\hline Within Groups & 47.933 & 87 & .551 & & \\
\hline Total & 1188.000 & 89 & & & \\
\hline
\end{tabular}

Table 4.12. Tukey Test Results for Vocabulary Retention in Delayed Thematic Test

\begin{tabular}{|c|c|c|c|c|c|c|}
\hline \multirow{2}{*}{$\begin{array}{l}\text { (I) } \\
\text { condition.th } \\
\text { ematic.1 }\end{array}$} & \multirow{2}{*}{$\begin{array}{c}(\mathrm{J}) \\
\text { condition.the } \\
\text { matic.1 }\end{array}$} & \multirow{2}{*}{$\begin{array}{c}\text { Mean } \\
\text { Difference } \\
\text { (I-J) }\end{array}$} & \multirow{2}{*}{ Std. Error } & \multirow{2}{*}{ Sig. } & \multicolumn{2}{|c|}{ 95\% Confidence Interval } \\
\hline & & & & & Lower Bound & Upper Bound \\
\hline \multirow{2}{*}{ Recalled } & Interfered & $7.56667^{*}$ & 19165 & .000 & 7.1097 & 8.0237 \\
\hline & Forgotten & $7.53333^{*}$ & 19165 & .000 & 7.0763 & 7.9903 \\
\hline \multirow{2}{*}{ Interfered } & Recalled & $-7.56667^{*}$ & 19165 & .000 & -8.0237 & -7.1097 \\
\hline & Forgotten & -.03333 & 19165 & 983 & -.4903 & 4237 \\
\hline \multirow{2}{*}{ Forgotten } & Recalled & $-7.53333^{*}$ & 19165 & .000 & -7.9903 & -7.0763 \\
\hline & Interfered & .03333 & .19165 & .983 & -.4237 & .4903 \\
\hline
\end{tabular}

* The mean difference is significant at the 0.05 level.

These inferential statistics show differences between the recalled and other conditions $(p=0.000)$, but no such differences are found between the interfered and forgotten types $(p=0.983)$. Therefore, in both immediate and delayed thematic tests, the vocabulary items have been interfered and forgotten by the learners to the same degree, showing no difference, but they recalled the items to a much greater degree.

In order to examine the general differences between the performance of learners with regard to the thematic and semantic clustering type, an independent samples T-test was conducted, the results of which are presented below 
Table 4.13. Descriptive Statistics Results for Semantic and Thematic Differences among Learners

\begin{tabular}{|l|l|l|l|l|l|}
\hline & clustering & $\mathrm{N}$ & Mean & Std. Deviation & Std. Error Mean \\
\hline \multirow{3}{*}{ Clustering } & Semantic & 180 & 3.3333 & 3.42518 & .25530 \\
\cline { 2 - 6 } & Thematic & 180 & 3.3333 & 3.87803 & .28905 \\
\hline
\end{tabular}

Table 4.14. Independent Samples T-test Results for Semantic and Thematic Differences among Advanced Learners

\begin{tabular}{|c|c|c|c|c|c|c|c|c|c|c|}
\hline & \multicolumn{2}{|c|}{$\begin{array}{l}\text { Levene's Test } \\
\text { for Equality } \\
\text { of Variances }\end{array}$} & \multicolumn{7}{|c|}{ t-test for Equality of Means } \\
\hline & & \multirow[t]{2}{*}{$\mathrm{F}$} & \multirow[t]{2}{*}{ Sig. } & \multirow[t]{2}{*}{$\mathrm{t}$} & \multirow[t]{2}{*}{$\mathrm{df}$} & \multirow[t]{2}{*}{$\begin{array}{l}\text { Sig. (2 } \\
\text { tailed) }\end{array}$} & \multirow[t]{2}{*}{$\begin{array}{l}\text { Mean } \\
\text { Difference }\end{array}$} & \multirow[t]{2}{*}{$\begin{array}{l}\text { Std. Error } \\
\text { Difference }\end{array}$} & \multicolumn{2}{|c|}{$\begin{array}{l}\text { 95\% Confidence } \\
\text { Interval of the } \\
\text { Difference }\end{array}$} \\
\hline & & & & & & & & & Lower & Upper \\
\hline \multirow[b]{2}{*}{1} & $\begin{array}{l}\text { Equal } \\
\text { variances } \\
\text { assumed }\end{array}$ & 8.514 & .004 & .000 & 358 & 1.000 & .00000 & .38565 & -.75843 & .75843 \\
\hline & $\begin{array}{l}\text { Equal } \\
\text { variances not } \\
\text { assumed }\end{array}$ & & & .000 & 3.5262 & 1.000 & .00000 & .38565 & -.75847 & .75847 \\
\hline
\end{tabular}

The results of independent samples T-test show no differences $(t(3.526)=0.000, p=1.000)$ between the thematic and semantic kinds of clustering in vocabulary retention of learners. The descriptive statistics, too, point to the same finding.

Below are results of independent samples T-test for the self-regulatory behavior of learners with regard to clustering types.

Table 4.15. Descriptive Statistics Results for Self-regulatory Differences among Learners

\begin{tabular}{|l|l|l|l|l|l|}
\hline & clustering2 & $\mathrm{N}$ & Mean & Std. Deviation & $\begin{array}{l}\text { Std. Error } \\
\text { Mean }\end{array}$ \\
\hline \multirow{2}{*}{ v2 } & semantic & 180 & 3.3333 & 2.81258 & .20964 \\
\cline { 2 - 6 } & thematic & 180 & 3.3333 & 2.70113 & .20133 \\
\hline
\end{tabular}

Table 4.16. Independent Samples T-test Results for Self-regulatory Differences among Learners

\begin{tabular}{|c|c|c|c|c|c|c|c|c|c|c|}
\hline & \multicolumn{2}{|c|}{$\begin{array}{l}\text { Levene's Test } \\
\text { for Equality of } \\
\text { Variances }\end{array}$} & \multicolumn{7}{|c|}{ t-test for Equality of Means } \\
\hline & & \multirow[t]{2}{*}{ F } & \multirow[t]{2}{*}{ Sig. } & \multirow[t]{2}{*}{$\mathrm{t}$} & \multirow[t]{2}{*}{ df } & \multirow[t]{2}{*}{$\begin{array}{l}\text { Sig. (2- } \\
\text { tailed) }\end{array}$} & \multirow[t]{2}{*}{$\begin{array}{l}\text { Mean } \\
\text { Difference }\end{array}$} & \multirow[t]{2}{*}{$\begin{array}{l}\text { Std. Error } \\
\text { Difference }\end{array}$} & \multicolumn{2}{|c|}{$\begin{array}{l}\text { 95\% Confidence } \\
\text { Interval of the } \\
\text { Difference }\end{array}$} \\
\hline & & & & & & & & & Lower & Upper \\
\hline \multirow{2}{*}{ v2 } & $\begin{array}{l}\text { Equal variances } \\
\text { assumed }\end{array}$ & .408 & .523 & .000 & 358 & 1.000 & .00000 & .29066 & -.57161 & .57161 \\
\hline & $\begin{array}{l}\text { Equal variances } \\
\text { not assumed }\end{array}$ & & & .000 & 3.5742 & 1.000 & .00000 & .29066 & -.57161 & .57161 \\
\hline
\end{tabular}


The results show no differences $(\mathrm{t}(358)=0.000, \mathrm{p}=1.000)$ between the semantic and thematic clustering with regard to learners' self-regulation.

\subsection{Discussion and Conclusions}

The present study aimed at the investigation of the differences between the semantic and thematic types of clustering on Iranian language learners' vocabulary retention. To this end, the study utilized an immediate and delayed post test to evaluate these effects. Results showed that learners could recall the vocabulary items in both the immediate and delayed post-tests. Another major and significant finding of the present study was that there were no differences between the semantic and thematic clustering types with regard to their impact on learners' vocabulary learning. This finding rejects the interference theory because learners were as successful in semantic clustering as they were in thematic clustering. There was no interference found between the similar items in the semantic sets as proposed by this theory. That is, both the semantic and thematic ways of presenting new and unknown vocabularies for learners seem to be effective. Moreover, the statistical results did not indicate a significant difference among participants' vocabulary learning in semantic and thematic conditions in terms of their selfregulation. In other words, participants of this study could exert control over their learning and were able to monitor and regulate their word learning process in both conditions.

The findings of the present research encourage an integrative approach to teaching vocabularies, emphasizing the importance of both the semantic and thematic approaches to vocabulary teaching. Traditionally, however, the assumption was that advanced and intermediate levels of proficiency learners would benefit from learning the vocabulary items via incidental and implicit learning methods. Krashen (1989) concluded that incidental vocabulary learning, or "acquisition", achieves better results than intentional vocabulary learning. A major flaw in this review lies in the assumption that "spelling and vocabulary are developed in second languages as they are in the first language" (p. 454). This indirect teaching of vocabulary assumes that vocabulary expansion will happen through the practice of other language skills, which has been proved not enough to ensure vocabulary expansion. Nowadays, it is widely accepted that vocabulary teaching should be part of the syllabus, and taught in a well-organized and planned basis. This is a way of teaching and learning called thematic clustering, whereby many areas of the curriculum are connected together and integrated within a theme. It allows learning to be more natural and less fragmented. It allows literacy to grow progressively, with vocabulary linked and with spelling and sentence writing being frequently, yet smoothly, reinforced. It also has the potential to guide integrated ideas to follow on easily. Explicit methods of teaching linguistic items including vocabulary items have proven to be successful too (DeKeyser, 2003). "There is a positive role for some kind of attention to form, that is, either through the explicit teaching of grammar and explicit error correction, or at least through more indirect means such as input enhancement" (DeKeyser, 2003, 321). It can be followed that according to DeKeyser, the explicit knowledge encouraged and taught by teachers can change into implicit knowledge. In other words, he is adopting the strong interface approach. DeKeyser believes that:

"Abstractness and distance play a major role in the differential effectiveness of implicit and explicit learning, along with rule scope, rule reliability, and salience. The harder it is to learn something through simple association, because it is too abstract, too distant, too rare, too unreliable, or too hard to notice, the more important explicit learning processes become” (p. 334).

The findings of the present study suggest that there are many factors that can affect the vocabulary learning ability of learners. What matters is the teachers' attention to the needs and 
purposes of the students who try to acquire the foreign language. As noted above, the findings of the present research suggest the importance of an integrative approach emphasizing the collaboration of both semantic and thematic approaches to vocabulary teaching and learning.

While some empirical evidence has suggested the effectiveness of simultaneous presentation of words (e.g., Crow, \& Quigley, 1985), other researchers warned us against the danger of presenting closely related new words at the same time (Higa, 1963; Nation, 1990; Tinkham, 1993; Waring, 1997). Specifically, Nation $(1990,191)$ maintained that when a group of related items require the same response from the learner, learning would be helped. On the other hand, if a different response is required for each item in a group of closely related items, the differences between the items will interfere with each other, thus making the learning task more difficult. "The network of associations between words in a native speaker's brain may be set as a goal for second language learners, but this does not mean that directly teaching these associations is the best way to achieve this goal" (Nation, 1990, 190). How much these associations in L1 and L2 correspond to each other, and how they can be employed to develop the L2 lexicon, need much more empirical exploration.

To help and strengthen the impact of semantic vocabulary learning, approaches to teaching should include thematic and context-based instructions too. It was concluded earlier that incidental learning alone is not enough in developing a functional vocabulary in a second or foreign language. Similarly, the intentional and direct learning of vocabulary does not, and should not, rule out contextual learning. In fact, learning new words from context might well be only the first step learners employ, and they should carry on, with metacognitive choice of words and treatment, to encode the new word together with the context where it appears (e.g., remembering the word together with the surrounding sentence). Some may even try to create a sentence using the new word and thus put it back into context (Sanaoui, 1995). Most empirical studies on contextual learning have compared incidental vocabulary learning from context with other forms of vocabulary presentation. Future research can examine how the other forms of contextual encoding (i.e., remembering new words with context, and using a new word in context) relate to other strategies and to learning results. 


\section{REFERENCES}

Al-Jabri, S. S. (2005). The effects of semantic and thematic clustering on learning English vocabulary by Saudi Students. Unpublished doctoral dissertation. Indiana University of Pennsylvania.

Amer, A. A. (1986). "Semantic Field Theory and Vocabulary Teaching”. English Teaching Forum, 24 (1), 30-31.

Barcroft, J. (2009). "Effects of Synonym Generation on Incidental And Intentional L2 Vocabulary Learning During Reading”. TESOL Quarterly, 43 (1), 79-103.

Bruton, A., López, M. G., \& Mesa, R. E. (2011). "Incidental L2 Vocabulary Learning: an Impracticable Term?”. TESOL Quarterly, 45, 759-768.

Celce-Murcia, M., \& Olshtain, E. (2000). Discourse and Context in Language Teaching. New York: Cambridge University Press.

Crow J. T., \& Quigley, J. R. (1985). “A Semantic Field Approach to Passive Vocabulary Acquisition for Reading Comprehension”. TESOL Quarterly, 19 (3), 497-513.

Crowder, R.G. (1976). Principles of Learning and Memory. Hillsdale, NJ: Lawrence Erlbaum Associates.

DeKeyser, R. (2003). “Implicit and Explicit Learning”. Eds. C. Doughty, \& M. Long. Handbook of Second Language Acquisition, 313-348. Oxford: Blackwell.

Dunbar, S. (1992). "Developing Vocabulary by Integrating Language and Context”. TESL Canada Journal, 9 (2), 73-79.

Erten, I. H., \& Tekin, M. (2008). "Effects of Vocabulary Acquisition of Presenting New Words in Semantic Sets Versus Semantically Unrelated Sets”. System, 36 (3), 407-22.

Eysenck, M. W. (1979). "Depth, Elaboration, and Distinctiveness”. Eds. S. Laird, Cermak, I., \& M. Fergus. Levels of Processing in Human Memory, 189-215. Hillsdale, NJ: Lawrence Erlbaum Associates.

Fillmore, C. J., \& Atkins, B. T. (1992). “Toward a Frame-Based Lexicon: the Semantics of RISK and Its Neighbors”. Eds. Lehrer, A., \& Kittay, E. F. Frames, Fields, and Contrasts, 75-102. Hillsdale, NJ: Erlbaum.

Finkbeiner, M., \& Nicol, J. (2003). "Semantic Category Effects in Second Language Word Learning”. Applied Psycholinguistics, 24, 369-383.

Gairns, R., \& Redman, S. (1986). Working With Words. Cambridge: Cambridge University Press.

Gass, S. (1999). “Incidental Vocabulary Learning”. Studies in Second Language Acquisition, 21 (2), 319-333.

Healey, D. (2000). “Approaches to Teaching Vocabulary, English Language Institute”. Eds. D. Healey, \& L. E. Bourne. Foreign language Learning, 89-93. Hillsdale, NJ: Lawrence Erlbaum Associates.

Higa, M. (1963). "Interference Effects of Intra-List Word Relationships in Verbal Learning”. Journal of Verbal Learning and Verbal Behavior, 2, 170-175.

Hoshino, Y. (2010). "The Categorical Facilitation Effects on L2 Vocabulary Learning in A Classroom Setting”. RELC Journal, 41 (3), 301-312.

Hulstijn, J. H. (1992). "Retention of Inferred and Given Word Meanings: Experiments in Incidental Vocabulary Learning”. Eds. P. J. L. Arnaud, \& H. Bejoint. Vocabulary and Applied Linguistic, 113125 London: Macmillan.

Hulstijn, J. H. (2001). "Intentional and Incidental Second Language Vocabulary Learning: A Reappraisal of Elaboration, Rehearsal and Automaticity”. Ed. P. Robinson. Cognition and Second Language Instruction, 258-286 Cambridge University Press.

Hunt, R. R., \& Worthen, J. B. (2006). Distinctiveness and Memory. Oxford: Oxford University Press.

Knight, S. (1994). "Dictionary Use While Reading: The Effects on Comprehension and Vocabulary Acquisition for Students of Different Verbal Abilities”. Modern Language Journal, 78, 285-298.

Krashen, S. (1989). "We acquire Vocabulary and Spelling by Reading: Additional Evidence for the Input Hypothesis”. The Modern Language Journal, 24, 237-270.

Kroll, J. F., \& Curley, J. (1988). "Lexical Memory in Novice Bilinguals: The Role of Concepts in Retrieving Second Language Words”. Eds. M. Gruneberg, P. Morris, \& R. Sykes. Practical Aspects 
of Memory, 389-395. London: Wiley.

Kroll, J. F., \& Stewart, E. (1994). "Category Interference in Translation and Picture Naming: Evidence for Asymmetric Connections Between Bilingual Memory Representations”. Journal of Memory and Language, 33 (2), 149-174.

Marzano, R. J., \& Marzano, J. S. (1988). A Cluster Approach to Elementary Vocabulary Instruction. Newark, DE: International Reading Association.

Meara, P., \& Fitzpatrick, T. (2000). "Lex 30: An Improved Method of Assessing Vocabulary in an L2”. System, 28, 19-30.

Miller, G. A., \& Gilda, R. P. M. (1987). “How Children Learn Words”. Scientific American, 8, 86-1.

Mirjalali, F., Jabbari, A. A., \& Rezai, M. J. (2012). "The Effect of Semantic and Thematic Clustering of Words on Iranians Vocabulary Learning". American International Journal of Contemporary Research, 2 (2), 214-222.

Motallebzadeh, K., \& Heirany, N. (2011). "Thematic Clustering Of L2 Vocabularies: A Technique for Improving Reading Comprehension Ability of Iranian Intermediate EFL Adult Learners". Iranian EFL Journal, 7, 1-15.

Murdock, B. B. (1962). "The Serial Position Effect in Free Recall”. Journal of Experimental Psychology, 64, 482-488.

Nation, I. S. P. (1990). Teaching and Learning Vocabulary. New York: Newbury House.

Nation, I. S. P. (2001). Learning Vocabulary in Another Language. Cambridge: Cambridge University Press.

Paribakht, T. S., \& Wesche, M. (1997). "Vocabulary Enhancement Activities and Reading for Meaning İn a Second Language Vocabulary Acquisition”. Eds. J. Coady, \& T. Huckin, 174-200. Second Language Vocabulary Acquisition. NY: Cambridge University Press.

Parry, K. (1997). "Vocabulary and Comprehension: Two Portrait”. Eds. J. Coady, \& T. Huckin. Second Language Vocabulary Acquisition: A Rationale for Pedagogy, 55-68. Cambridge University Press.

Prince, P. (1996). "Second Language Vocabulary Learning: The Role of Context Versus Translations as a Function of Proficiency". Modern Language Journal, 80, (4), 478-493.

Read, J. (2004). "Research in Teaching Vocabulary”. Annual Review of Applied Linguistics, 24 (1), 146161.

Sanaoui, R. (1995). “Adult Learners’ Approaches to Learning Vocabulary in Second Languages”. The Modern Language Journal, 79, 15-28.

Seal, B. D. (1991). "Vocabulary Learning and Teaching”. Ed. M. Celce-Murcia. Teaching English as a Second or Foreign Language, 296-311. Heinle and Heinle Publishers.

Segal, M. A., \& Mandler, G. (1967). "Directionality and Organizational Processes in Paired-Associate Learning”. Journal of Experimental Psychology, 74, 305-312.

Schmitt, N. (1999). "The Relationship Between TOEFL Vocabulary Items and Meaning, Association, Collocation and Word-Class Knowledge”. Language Testing, 16, 189-216.

Tagashira, K., Kida, S., \& Hoshino, Y. (2010). "Hot or gelid? The Influence of L1 Translation Familiarity on the Interference Effects in Foreign Language Vocabulary Learning”. System, 38 (3), 412-421.

Tinkham, T. (1993). "The Effect of Semantic Clustering on the Learning of Second Language Vocabulary”. System, 21 (3), 371-80.

Tinkham, T. (1997). "The Effects of Semantic and Thematic Clustering on the Learning of Second Language Vocabulary”. Second Language Research, 13 (2), 138-63.

Tulving, E. (1968). "Theoretical Issues in Free Recall”. Eds. T. R. Dixon, \& D. L. Horton. Verbal Behavior and General Behavior Theory. Englewood Cliffs, NJ.: Prentice-Hall.

Waring, R. (1997). "The Negative Effects of Learning Words in Semantic Sets: A replication”. System, 25 (2), 261-74. 


\section{APPENDIX A}

Plummet: Is a weight usually with a pointed tip on the bottom which is suspended from a string and used as a vertical reference. Example: David wanted to make sure that the 10-meter wall was completely straight, for this purpose he used a plummet.

Mattock: A tool used for digging with a long handle and metal blade. Example: John decided to dig a pit in the hard ground; so he used a mattock to penetrate to the ground and then used a shovel to move the soil.

Trowel: A small tool with a flat blade used for spreading cement on bricks. Example: Ali used his trowel to spread the cement on the ground, and then he put the ceramic tiles on cement after another.

Adz: An adz is a hand-tool similar to a hammer with a sharp blade at one side used for smoothing or carving. Example: Since he was an experienced worker he could break the brick into two same pieces with an adz.

Spatula: Is a tool with a broad, flat, flexible blade used to mix, spread and lift materials. Example: After the workers finished repairing the ceiling he noticed that there is some cement dried on the ground so he bought a spatula to remove the hard cement.

Sifter: Is a tool used to separate wanted elements from unwanted material using a woven screen such a net. Example: Thomas used a sifter to separate the small pieces of brick that unintentionally had mixed with cement powder.

$$
\text { (غَرَبال- سَرَنْان }
$$

Burin: Is a metal tool with a relatively dull head that breaks rather than cuts. Normally used as a demolition tool and used with a heavy hammer. The Burin is held with one hand and struck with a hammer. Example: When Robert came in he saw that the new workers had installed the bathtub in the wrong place; so the workers demolished it using a burin and sledgehammer.

$$
\text { (قَّلم تخريب) }
$$

Sledgehammer: A sledgehammer is a tool consisting of a large, heavy head attached to a handle. The head is typically made of metal. The sledgehammer can apply more force than other hammers, due to its large size. Example: Kevin decided to expand his shop by joining to the neighboring store; so he asked the worker to destroy the wall in between, and they did that with big Sledgehammers.

Pulley: A piece of equipment consisting of a wheel over a rope or chain is pulled to lift heavy things. Example: Daniel was on the roof of the house and asked Devin to bring him a bucket full of dry cement; since it was too heavy to carry up to the roof, Devin used a pulley to take it to the roof.

$$
\text { (طَناب و قِرقِرْه) }
$$

Rake: Is a tool with a row of metal teeth at the end of a long handle, used for making soil level, and gathering up dead leaves. If the rake lies in the ground teeth up, and someone accidentally steps on the teeth, the rake's handle can swing rapidly upwards, colliding with the victim's face. This is often seen in cartoons, such as Tom and Jerry. Example: James used a rake to change the level of the soil and allow the

\begin{tabular}{|c|c|c|c|}
\hline $\mathrm{Adz}$ & (1) & Plummet & 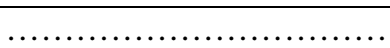 \\
\hline Rake & & Burin & 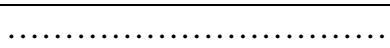 \\
\hline Sifter & n............. & Mattock & .......... \\
\hline
\end{tabular}
water to flow. 


\begin{tabular}{|c|c|c|c|}
\hline Trowel & 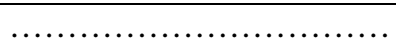 & Sledgehammer & \\
\hline Spatula & 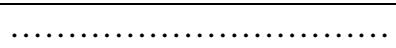 & Pulley & $\ldots \ldots$ \\
\hline
\end{tabular}

\section{APPENDIX B}

Bolster: Is a long narrow pillow or cushion filled with cotton, or fiber. Example: Since the weather was so nice Ali decided to take a bolster in order to take a nap when they get to the heights.

Quilt: Is a type of bed cover, or a thick protective cover. Example: Reza took a large and thick quilt, because he knew that the surface of the ground for the picnic is not smooth.

Lantern: Is a portable lighting device. Example: They thought that the lantern would be an unnecessary device to pack, but it really helped them to fix the car when they were out of the city at midnight.

$$
\text { (جراغ سيار، جراغ دسني) }
$$

*Esky: Is a portable ice chest, or insulated box used to keep food or drink cool. Example: He put the bottles of beverage with a large block of ice in the Esky to keep them cool in the hot summer.

Hamper: Is a basket with a lid which is used for the transport of items, often food. Example: We put the sandwiches in a small hamper to be in hand when we are on the way.

$$
\text { (سبد،زنبيل) }
$$

Brochettea: Is a long metal or wooden stick, used for holding pieces of meat, etc, while roasting or grilling. Example: When we wanted to roast the meat on fire we noticed that we have left the brochettea at home; and instead we used a tree's branch as a brochettea.

$$
\text { (سيخ كباب) }
$$

Log: Sections of trimmed timber. Example: We could gather a large pile of log for having a big fire and also keep it on for the rest of the day.

Arduous (road): Hard to move, overcome, and climb. Example: He told us not to take this road because it's an arduous road even for experienced drivers.

$$
\text { (صعب العبور) }
$$

Bog: To stuck in soft ground and unable to move. Example: Due to the heavy raining in this area we finally bogged.

$$
\text { (در كل كير (فتادن) }
$$

\begin{tabular}{|c|c|c|c|}
\hline Quilt & (n) & Lantern & (n. \\
\hline Brochettea & n.w. & Esky & …............. \\
\hline Bolster & 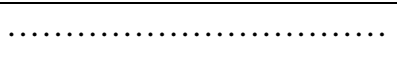 & Rev & \\
\hline Arduous (road) & (n) & Bog & 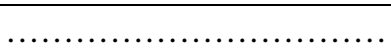 \\
\hline Hamper & 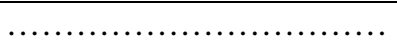 & $\log$ & \\
\hline
\end{tabular}

Rev: To make an engine work faster. Example: Since he is bogged he is revving up in order to get out, but he does not know that he is making the situation worse.

(كاز دادن به ماشين) 